University of Nebraska - Lincoln

DigitalCommons@University of Nebraska - Lincoln

\title{
Efficacy Of Three Attractant Blends Tested In Combination With Carbon Dioxide Against Natural Populations Of Mosquitoes And Biting Flies At The Lower Suwannee Wildlife Refuge
}

\author{
Daniel L. Kline \\ United States Department of Agriculture \\ Ulrich R. Bernier \\ University of Florida, ubernier@gainesville.usda.ufl.edu \\ Jerome A. Hogsette \\ United States Department of Agriculture
}

Follow this and additional works at: https://digitalcommons.unl.edu/usdaarsfacpub

Part of the Agricultural Science Commons

\footnotetext{
Kline, Daniel L.; Bernier, Ulrich R.; and Hogsette, Jerome A., "Efficacy Of Three Attractant Blends Tested In Combination With Carbon Dioxide Against Natural Populations Of Mosquitoes And Biting Flies At The Lower Suwannee Wildlife Refuge" (2012). Publications from USDA-ARS / UNL Faculty. 999.

https://digitalcommons.unl.edu/usdaarsfacpub/999
}

This Article is brought to you for free and open access by the U.S. Department of Agriculture: Agricultural Research Service, Lincoln, Nebraska at DigitalCommons@University of Nebraska - Lincoln. It has been accepted for inclusion in Publications from USDA-ARS / UNL Faculty by an authorized administrator of DigitalCommons@University of Nebraska - Lincoln. 


\title{
SCIENTIFIC NOTE
}

\section{EFFICACY OF THREE ATTRACTANT BLENDS TESTED IN COMBINATION WITH CARBON DIOXIDE AGAINST NATURAL POPULATIONS OF MOSQUITOES AND BITING FLIES AT THE LOWER SUWANNEE WILDLIFE REFUGE}

\author{
DANIEL L. KLINE, ULRICH R. BERNIER AND JEROME A. HOGSETTE
} United States Department of Agriculture-Agricultural Research Service, Center for Medical, Agricultural, and
Veterinary Entomology, 1600 SW 23rd Drive, Gainesville, FL 32608

\begin{abstract}
Synthetic blends of chemicals identified previously from human skin emanations were evaluated against mosquito and biting fly populations at the Lower Suwannee Wildlife Refuge near Cedar Key, FL. Mosquito Magnet ${ }^{\mathrm{TM}}$-Experimental traps were baited with the Red (400 ml acetone:10 ml 1-hexen3-ol:10 ml 1-octen-3-ol), Blue (400 ml acetone: $1 \mathrm{~g} /$ liter lactic acid:20 ml glycolic acid), or Green blend (400 ml acetone: $1.5 \mathrm{~g}$ /liter lactic acid:20 ml dimethyl disulfide) plus $\mathrm{CO}_{2}$ or with $\mathrm{CO}_{2}$ alone (control). A relative index of efficacy was determined by dividing each mean blend trap catch by the mean control trap catch. Five mosquitoes (Aedes infirmatus, Ae. taeniorhynchus, Ae. triseriatus, Anopheles crucians, and Culex nigripalpus), 2 ceratopogonid (Culicoides floridensis and C. furens), and 1 tabanid (Diachlorus ferrugatus) and phlebotomine (Lutzomyia shannoni) species were trapped. The Red blend $+\mathrm{CO}_{2}$ treatment significantly increased collections of Ae. taeniorhynchus $(3.4 \times)$, An. crucians $(2.8 \times)$, total mosquitoes $(2.7 \times)$, C. furens $(17.6 \times)$, and L. shannoni $(10.8 \times)$ compared with control traps. Traps baited with either the Blue or Green blends generally captured fewer insects than traps baited with the other 2 treatments. However, traps baited with the Green blend caught $7 \times$ as many $C$. furens as the control traps. Responses clearly varied according to species; therefore, "one size does not fit all" when it comes to attractant blends.
\end{abstract}

KEY WORDS Aedes taeniorhynchus, Culex nigripalpus, Culicoides, Diachlorus ferrugatus, Lutzomyia shannoni

Synthetic blends of chemicals have been evaluated against mosquitoes and other biting insects under laboratory and field conditions. From observations made in a dual-choice olfactometer, Acree et al. (1968) determined that Llactic acid attracted female Aedes aegypti (L.), but the attraction was not great. In subsequent trials, Schreck and James (1968) demonstrated that $\mathrm{CO}_{2}$ activated the flight of Ae. aegypti females toward an odor source. Smith et al. (1970) produced a strong synergistic attraction response by using Llactic acid in combination with $\mathrm{CO}_{2}$. Schreck et al. $(1981,1990)$ showed that unidentified human skin emanations play a role in the attraction of female Ae. aegypti to humans, which could explain the differential attraction among individuals. Using purge and trap gas chromatography/ mass spectrometry, $>300$ compounds from human skin were identified (Bernier et al. 2000, 2002). Twenty-six compounds were of background origin, leaving 277 as candidate Ae. aegypti attractants. Carboxylic and lactic acids were present in the highest amounts in the moderately volatile emanations (Bernier et al. 2000). Additional studies with more volatile components revealed that acetone was the most abundant component emanating from the human hand (Bernier et al. 2007b).
In triple-cage, dual-port, dual-choice olfactometer studies, acetone, 1-hexen-3-ol (hexenol), glycolic acid, acetone, dimethyl disulfide (DMDS), and lactic acid produced the best attractant responses in female Ae. aegypti (Posey et al. 1998, Bernier et al. 2001). Bernier et al. (2003) found that binary combinations of these chemicals were very attractive to mosquitoes, and that several binary and tertiary blends (e.g., acetone + DMDS + lactic acid) were highly attractive, even without $\mathrm{CO}_{2}$ (Bernier et al. 2007a).

Earlier studies have also shown 1-octen-3-ol (octenol) as a promising attractant for mosquitoes in a variety of habitats (Takken and Kline 1989; Takken 1991; Kline et al. 1990a, 1990b, 1991a, 1991b), biting midges (Kline et al. 1994), and tabanids (French and Kline 1989); and that an octenol/ $\mathrm{CO}_{2}$ combination attracted some species more efficiently than others. In olfactometer trials, hexenol and octenol combined produced good (ca. 50\%) attractant responses in female Ae. aegypti and Anopheles albimanus Wiedemann, but very poor $(<10 \%)$ in Culex quinquefasciatus Say. Responses by Ae. aegypti were greater to the combination than to either compound alone. Very good responses $(>80 \%)$ were also observed in to blends consisting of either glycolic acid + acetone, or glycolic acid + 


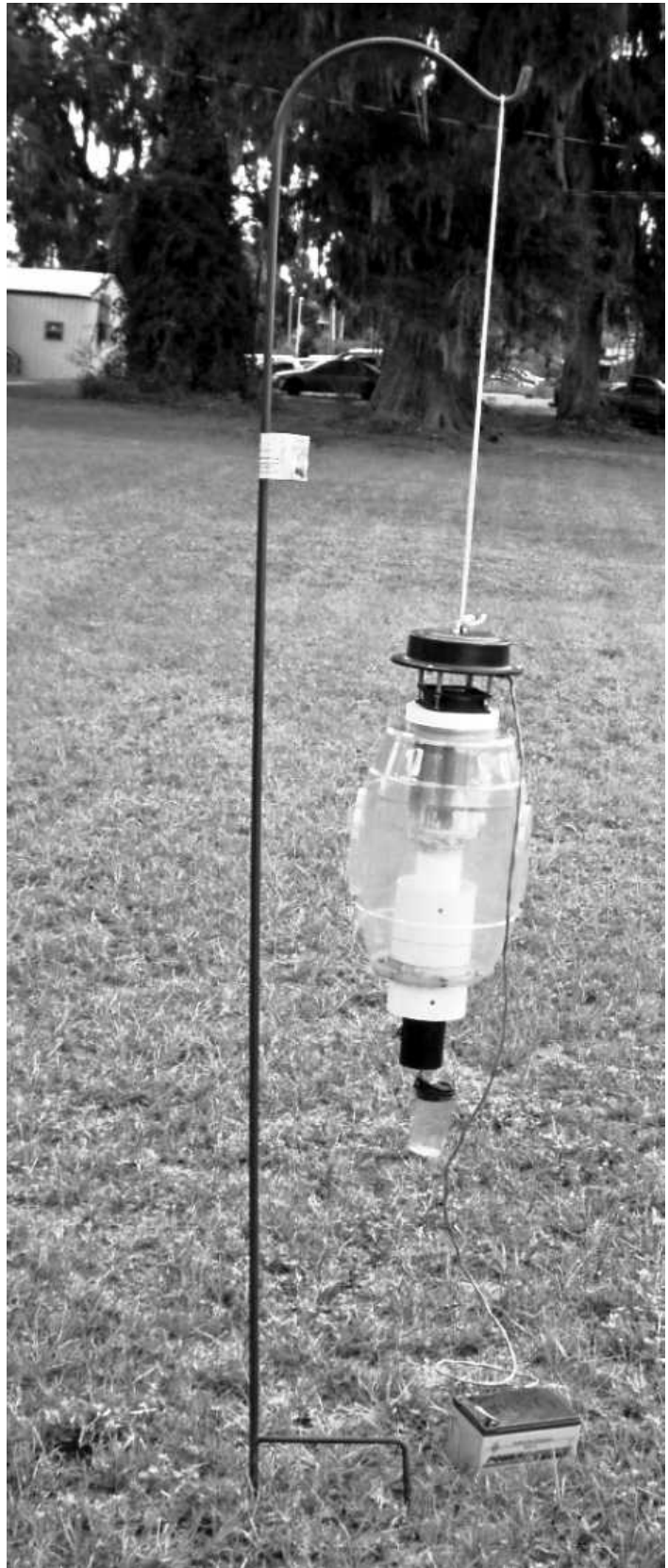

Fig. 1. Mosquito Magnet ${ }^{\mathrm{TM}}$-Experimental trap with jar of blend suspended near the carbon dioxide outlet port.

acetone + lactic acid (Kline, unpublished data). Responses to compounds/blends in laboratory olfactometer studies may differ from those of field populations of mosquitoes or biting flies. The present field study was carried out to determine if traps baited with blends of selected compounds from human skin emanations in combination with $\mathrm{CO}_{2}$ would capture greater numbers of mosquitoes and/or biting flies than traps baited with $\mathrm{CO}_{2}$ alone.

Experiments were conducted at the Lower Suwannee Wildlife Refuge, near Cedar Key, FL, with natural populations of salt-marsh and woodland mosquitoes and biting flies. This ca. 21,448 -ha $(53,000$-acre) refuge contains a diversity of habitats that provide numerous developmental sites for a large variety of target species. Four Mosquito Magnet-Experimental (MM-X; American Biophysics Corp., North Kingston, RI) counterflow geometry traps, which are not sold commercially, were used to evaluate our candidate blends. Counterflow technology utilizes an outgoing airflow to disseminate attractive lures and an incoming airflow to suck insects into a collecting chamber (Kline 1999). Trap fans were powered by rechargeable $12-\mathrm{V}$ batteries. The $\mathrm{CO}_{2}$ was supplied by $9-\mathrm{kg}$ compressed-gas cylinders equipped with FLOWSET1 pressure regulators (Clarke, Roselle, IL) with a fixed output of 15 psi, a $10-\mu \mathrm{m}$ line filter, and a 0.007 in-line orifice, which maintained the flow rate at $500 \mathrm{ml} / \mathrm{min}$. Polythene tubing (outer diam: $8 \mathrm{~mm}$ ) equipped with quick-connect lure fittings at both ends connected the regulator assembly with the MM-X trap.

Three candidate blends were designated as Red, Blue, or Green to provide a blind test. The Red blend consisted of $400 \mathrm{ml}$ acetone, $10 \mathrm{ml} 1$ hexen-3-ol, and $10 \mathrm{ml}$ 1-octen-3-ol; the Blue blend consisted of $400 \mathrm{ml}$ acetone, $1 \mathrm{~g} / \mathrm{liter}$ lactic acid, and $20 \mathrm{ml}$ glycolic acid; the Green blend consisted of $400 \mathrm{ml}$ acetone, $1.5 \mathrm{~g} /$ liter lactic acid, and $20 \mathrm{ml}$ DMDS. The L-lactic acid (99\% purity) was purchased from Fluka (Milwaukee, WI). Remaining reagent-grade chemicals ( $\geq 97 \%$ purity) were purchased from Sigma-Aldrich (Milwaukee, WI). Blends were released from Quorpak ${ }^{\circledR}$ (Bridgeville, PA) 120-ml clear glass jars (40-mm mouth opening, lids removed) suspended below the traps near the $\mathrm{CO}_{2}$ outlet (Fig. 1). Blends in Quorpak jars were brought up to the 120-ml level after daily insect removal.

The experimental design was a $4 \times 4$ Latin square and 4 treatments were evaluated. Three traps were baited with $500 \mathrm{ml} / \mathrm{min} \mathrm{CO}_{2}$ plus 1 of 3 blends; 1 trap served as a control and was baited only with $500 \mathrm{ml} / \mathrm{min} \mathrm{CO}_{2}$. The MM-X traps were placed ca. $160 \mathrm{~m}$ apart along a dirt road that transected a mixture of bottomland hardwood swamp and salt-marsh habitats. Traps were suspended from shepherd's hooks so that the lowest point of each trap was ca. 15-20 cm above the ground. Traps were operated continuously for ca. $23 \mathrm{~h}$ each trapping day, beginning at $2 \mathrm{~h}$ before sunset. On the 1st night of testing, the treatments were randomly assigned to trap stations. On subsequent nights, the treatments were rotated to the next station until all treatments were tested at each station. 
Table 1. Mean ${ }^{1}( \pm \mathrm{SE})$ and index ${ }^{2}$ of insect species captured with blend treatments $1-4(n=4)$.

\begin{tabular}{|c|c|c|c|c|c|c|c|}
\hline \multirow[b]{2}{*}{ Insects } & \multirow{2}{*}{$\begin{array}{l}\text { Control treat- } \\
\text { ment } 1\left(\mathrm{CO}_{2}\right. \\
\text { alone })\end{array}$} & \multicolumn{2}{|c|}{ Red Blend treatment 2} & \multicolumn{2}{|c|}{ Blue Blend treatment 3} & \multicolumn{2}{|c|}{ Green Blend treatment 4} \\
\hline & & $\left(+\mathrm{CO}_{2}\right)$ & Index & $\left(+\mathrm{CO}_{2}\right)$ & Index & $\left(+\mathrm{CO}_{2}\right)$ & Index \\
\hline Aedes infirmatus & $32.3 \pm 1.5 \mathrm{ab}$ & $66.1 \pm 1.3 \mathrm{a}$ & 2.04 & $24.7 \pm 1.8 b$ & 0.76 & $20.9 \pm 1.7 b$ & 0.64 \\
\hline Ae. taeniorhynchus & $249.2 \pm 1.3 b$ & $838.1 \pm 1.1 \mathrm{a}$ & 3.36 & $139.5 \pm 1.5 b$ & 0.56 & $207.1 \pm 1.1 b$ & 0.84 \\
\hline Ae. triseriatus & $2.2 \pm 1.6 \mathrm{a}$ & $4.3 \pm 1.9 \mathrm{a}$ & 2.93 & $2.5 \pm 1.1 \mathrm{a}$ & 1.11 & $2.0 \pm 1.3 \mathrm{a}$ & 0.90 \\
\hline Anopheles crucians & $55.0 \pm 1.6 b$ & $155.4 \pm 1.6 \mathrm{a}$ & 2.82 & $30.5 \pm 2.0 b$ & 0.55 & $48.2 \pm 2.1 b$ & 0.88 \\
\hline Culex nigripalpus & $55.2 \pm 1.6 \mathrm{a}$ & $16.9 \pm 1.4 b$ & 0.30 & $11.0 \pm 1.7 \mathrm{~b}$ & 0.20 & $10.0 \pm 1.9 b$ & 0.18 \\
\hline Total mosquitoes & $431.4 \pm 1.3 b$ & $1177.9 \pm 1.1 \mathrm{a}$ & 2.73 & $222.8 \pm 1.6 \mathrm{c}$ & 0.52 & $330.0 \pm 1.3 \mathrm{bc}$ & 0.74 \\
\hline Culicoides floridensis & $468.1 \pm 1.7 \mathrm{a}$ & $234.0 \pm 2.0 \mathrm{a}$ & 0.49 & $363.9 \pm 2.5 \mathrm{a}$ & 0.78 & $293.5 \pm 1.8 \mathrm{a}$ & 0.63 \\
\hline C. furens & $16.2 \pm 2.3 b$ & $285.8 \pm 2.6 \mathrm{a}$ & 17.64 & $17.0 \pm 1.8 b$ & 1.05 & $114.2 \pm 1.5 \mathrm{ab}$ & 7.05 \\
\hline Diachlorus ferrugatus & $14.0 \pm 1.4 \mathrm{a}$ & $37.1 \pm 1.5 \mathrm{a}$ & 2.66 & $10.4 \pm 1.3 \mathrm{a}$ & 0.75 & $11.5 \pm 2.4 \mathrm{a}$ & 0.82 \\
\hline Lutzomyia shannoni & $16.4 \pm 2.0 \mathrm{~b}$ & $176.9 \pm 1.5 \mathrm{a}$ & 10.81 & $10.1 \pm 2.3 b$ & 0.62 & $8.2 \pm 1.7 \mathrm{~b}$ & 0.50 \\
\hline
\end{tabular}

${ }^{1}$ Means in rows followed by the same letter are not significantly different $(P<0.05$; Ryan-Einot-Gabriel-Welsch multiple range test [SAS/STAT user's guide, version 9.2; SAS Institute, Cary, NC]).

${ }^{2}$ Index $=$ Blend treatment mean/Control treatment mean.

Data were subjected to the General Linear Models procedure to determine the effects of treatment (blend), trap location, and trap day on numbers of insects captured. Means were separated with the Ryan-Einot-Gabriel-Welsh multiple range test (SAS/STAT user's guide, version 9.2.; SAS Institute, Cary, NC) and, unless otherwise stated, $P=0.05$. Insect capture data were transformed with $\log _{10}(n+1)$ prior to analysis but back-transformed numbers are shown in text and tables. A relative index of efficacy was calculated by dividing the mean trap catch for each blend by the mean control trap catch.

Five mosquito species (Ae. infirmatus Dyar and Knab, Ae. taeniorhynchus (Wiedemann), Ae. triseriatus (Say), An. crucians Wiedemann, and Cx. nigripalpus Theobald), 2 ceratopogonid species (Culicoides floridensis Beck and C. furens (Poey)), and 1 tabanid (Diachlorus ferrugatus (Fabricius)) and 1 phlebotomine species (Lutzomyia shannoni Dyar) were caught (Table 1). The mean numbers of Ae. taeniorhynchus, An. crucians, total mosquitoes, $C$. furens, and $L$. shannoni captured with the Red blend $+\mathrm{CO}_{2}$ were significantly greater than those captured with $\mathrm{CO}_{2}$ alone. The Red blend $+\mathrm{CO}_{2}$ increased mean captures of Ae. infirmatus $(2.04 \times)$, Ae. triseriatus $(2.04 \times)$, and D. ferrugatus $(2.66 \times)$ compared with $\mathrm{CO}_{2}$ alone, but results were not significant. Mean numbers of $C x$. nigripalpus captured with the Red blend $+\mathrm{CO}_{2}$ were significantly smaller than those captured with $\mathrm{CO}_{2}$ alone, but the collection size of $C$. floridensis was numerically but not significantly smaller. Traps baited with the Red blend $+\mathrm{CO}_{2}$ caught statistically more of all individual species and total mosquitoes, except Ae. triseriatus, Cx. nigripalpus, C. floridensis, and D. ferrugatus when compared with traps baited with the Blue blend $+\mathrm{CO}_{2}$. Only $C$. floridensis was caught in numerically but not significantly greater numbers with the Blue (363.9) compared with the Red (234.0) blend $+\mathrm{CO}_{2}$. When traps baited with the Red blend $+\mathrm{CO}_{2}$ and the Green blend $+\mathrm{CO}_{2}$ were compared, trends were similar to those observed with the Red versus Blue blend comparison. However, mean numbers of $C$. furens captured with the Green blend $+\mathrm{CO}_{2}$ and the Red blend $+\mathrm{CO}_{2}$ were not significantly different. Mean numbers of insects captured with the Blue and Green blends $+\mathrm{CO}_{2}$ were not significantly different. Baiting the traps with any of the 3 blends statistically reduced collections of $C x$. nigripalpus when compared with traps baited $\mathrm{CO}_{2}$ alone. Also, traps baited with the Blue blend $+\mathrm{CO}_{2}$ captured statistically fewer total mosquitoes than traps baited with the Red blend $+\mathrm{CO}_{2}$ or $\mathrm{CO}_{2}$ alone.

Data from the present study show that compounds used in blends may either synergize or antagonize each other's activity in the presence of $\mathrm{CO}_{2}$ at the behavioral response level. The response can vary according to species. For all species except $C x$. nigripalpus, trap collections were increased when the Red blend $+\mathrm{CO}_{2}$ was used, compared with traps baited with $\mathrm{CO}_{2}$ alone. For most species, collections were reduced when the Blue or Green blend was used. The Blue blend had a neutral effect on Ae. triseriatus and $C$. furens. Blend components alone and in various combinations produced high attractive responses by $A$ e. aegypti in olfactometer studies (Bernier et al. 2001, 2003). A combination of hexenol + octenol (without acetone or $\mathrm{CO}_{2}$ ) was the only blend tested against $C x$. quinquefasciatus, showing a very poor response (Bernier, unpublished data). This was supported by Mboera et al. (2000). Very good attractive responses $(>80 \%)$ by Ae. aegypti to blends consisting of either glycolic acid + acetone, or glycolic acid + acetone + lactic acid (Bernier and Kline, unpublished data) were also documented with Ae. albopictus (Skuse) (Bernier et al. 2001).

Of particular interest is the performance of traps baited with the Red blend. As previously 
stated, the combination of hexenol + octenol resulted in greater responses of both Ae. aegypti and An. albimanus than the single components in olfactometer tests (Kline and Bernier, unpublished data). We are not aware of previous field studies conducted using hexenol as an attractant. Since we conducted our field studies, Mann et al. (2009) found that L. shannoni preferred MM-X traps baited with Red blend $+\mathrm{CO}_{2}$ over traps baited with $\mathrm{CO}_{2}$ alone. This supports our findings for this species. Many studies have been conducted with octenol alone and in combination with $\mathrm{CO}_{2}$. Trends seen in our study resemble those reported previously. It is difficult to determine from our data whether hexenol contributed to the attractiveness of the Red blend. However, it appears that the effectiveness of octenol is not decreased by hexenol. Future studies should be conducted with blends consisting of octenol + acetone, hexenol + acetone, octenol + hexenol + acetone, and acetone alone with and without $\mathrm{CO}_{2}$

We are unaware of any published field studies with either glycolic acid or DMDS. There are an increasing number of published field studies in which L-lactic acid is a major component of blends (Smallengange et al. 2005). BioGents (BioGents GmbH, Regensburg, Germany) developed and commercialized the BG-Lure, which consists of lactic acid, ammonia, and caproic acid, all substances found on human skin (Krockel et al. 2006). This lure was specifically developed to attract host-seeking female $A e$. aegypti without the use of $\mathrm{CO}_{2}$. This lure has also been used successfully to attract other Aedes (Stegomyia) species, such as Ae. polynesiensis Marks (Schmaedick et al. 2008) and Ae. albopictus (Cilek et al. 2011, Meeraus et al. 2008), and also Cx. quinquefasciatus (Cilek et al. 2011). When the traps were baited with a combination of $\mathrm{CO}_{2}+$ BG-Lure, Ae. albopictus collections increased $6 \times$; this combination also increased the collection size of 13 of the other 17 mosquito species. In traps baited with $\mathrm{CO}_{2}$ alone, the collections of Ae. albopictus decreased, but trap collections of all Anopheles, Coquillettidia, Psorophora, and most Culex and woodland floodwater species of Aedes increased 2-4× compared to the traps baited with a combination of $\mathrm{CO}_{2}+$ BG-Lure. This implies that the BG-Lure contains at least one chemical compound that adversely affects the collection of most mosquito species. This trend is similar to the results we obtained with our Blue and Green blends.

These data demonstrate that "one size does not fit all" when it comes to attractant blends. Part of this may be related to host-preference differences in the various species collected. A major part of this may also come from the odors by the blend components being an imperfect approximation of the complex odor profile produced by a living host. More research is needed to develop the right blends for different species of mosquitoes and biting flies.

\section{REFERENCES CITED}

Acree F Jr, Turner RB, Gouck HK, Beroza M. 1968. LLactic acid: a mosquito attractant isolated from humans. Science 161:1346-1347.

Bernier UR, Kline DL, Allan SA, Barnard DR. 2007a. Laboratory comparison of Aedes aegypti (L.) attraction to human odors and to synthetic human odor compounds and blends. J Am Mosq Control Assoc 23:288-293.

Bernier UR, Kline DL, Barnard DR, Posey KH, Booth MM, Yost RA, inventors; USA as represented by the Secretary of Agriculture, Washington, DC, assignee. 2001 July 31. Chemical composition that attract arthropods. United States patent US 6,267,953.

Bernier UR, Kline DL, Barnard DR, Schreck CE, Yost RA. 2000. Analysis of human skin emanations by gas chromatography/mass spectrometry. 2. Identification of volatile compounds that are candidate attractants for yellow fever mosquito (Aedes aegypti). Anal Chem 72:747-756.

Bernier UR, Kline DL, Posey KH. 2007b. Human emanations and related natural compounds that inhibit mosquito host-finding ability. In: Debboun $\mathrm{M}$, Frances $\mathrm{S}$, Strickman $\mathrm{D}$, eds. Insect repellents: principles, methods, and use. Boca Raton, FL: CRC Press. p 77-100.

Bernier UR, Kline DL, Posey KH, Booth MM, Yost RA, Barnard DR. 2003. Synergistic attraction of Aedes aegypti (L.) to binary blends of L-lactic acid, acetone, dichloromethane, or dimethyl disulfide. $J$ Med Entomol 40:653-656.

Bernier UR, Kline DL, Schreck CE, Yost RA, Barnard DR. 2002. Chemical analysis of human skin emanations: comparison of volatiles from humans that differ in attraction of Aedes aegypti (Diptera: Culicidae). J Am Mosq Control Assoc 18:186-195.

Cilek JE, Hallmon CF, Johnson R. 2011. Semi-field comparison of the BG lure, nonanal, and 1-octen-3-ol to attract adult mosquitoes in NW Florida. $J \mathrm{Am}$ Mosq Control Assoc 27:393-397.

French FE, Kline DL. 1989. 1-Octen-3-ol, an attractant for Tabanidae (Diptera). J Med Entomol 26:459-461.

Kline DL. 1999. Comparison of two American Biophysics mosquito traps: the professional and a new counterflow geometry trap. J Am Mosq Control Assoc 15:276-282.

Kline DL, Dame DA, Meisch MV. 1991a. Evaluation of 1-octen-3-ol and carbon dioxide as attractants for mosquitoes associated with irrigated rice fields in Arkansas. J Am Mosq Control Assoc 7:165-169.

Kline DL, Hagan DV, Wood JR. 1994. Culicoides responses to 1-octen-3-ol and carbon dioxide in salt marshes near Sea Island, Georgia, U.S.A. Med Vet Entomol 8:25-30.

Kline DL, Takken W, Wood JR, Carlson DA. 1990a. Field studies on the potential of butanone, carbon dioxide, honey extract, 1-octen-3-ol, L-lactic acid and phenols as attractants for mosquitoes. Med Vet Entomol 4:383-391.

Kline DL, Wood JR, Cornell JA. 1991b. Interactive effects of 1-octen-3-ol and carbon dioxide on 
mosquito (Diptera: Culicidae) surveillance and control. J Med Entomol 28:254-258.

Kline DL, Wood JR, Morris CD. 1990b. Evaluation of 1-octen-3-ol as an attractant for Coquillettidia perturbans, Mansonia spp. and Culex spp. associated with phosphate mining operations. $J$ Am Mosq Control Assoc 6:605-611.

Krockel U, Rose A, Eiras AE, Geier M. 2006. New tools for surveillance of adult yellow fever mosquitoes: comparison of trap catches with human landing rates in an urban environment. J Am Mosq Control Assoc 22:229-238.

Mann RS, Kaufman PE, Butler JF. 2009. Lutzomyia spp. (Diptera: Psychodidae) response to olfactory attractant- and light emitting diode-modified Mosquito Magnet-X (MM-X) traps. J Med Entomol 46:1052-1061

Mboera LEG, Takken W, Sambu EZ. 2000. The response of Culex quinquefasciatus (Diptera: Culicidae) to traps baited with carbon dioxide, 1-octen-3ol, acetone, butyric acid, and human foot odour in Tanzania. Bull Entomol Res 90:155-159.

Meeraus WH, Armistead JS, Arias JR. 2008. Field comparison of novel and gold standard traps for collecting Aedes albopictus in Northern Virginia. J Am Mosq Control Assoc 24:244-245.

Posey KH, Barnard DR, Schreck CE. 1998. Triple cage olfactometer for evaluating mosquito (Diptera: Culicidae) attraction responses. $J$ Med Entomol 35:330-334.
Schmaedick MA, Ball TS, Burkot TR, Gurr NE. 2008. Evaluation of three traps for sampling Aedes polynesiensis and other mosquito species in American Samoa. J Am Mosq Control Assoc 24:319-322.

Schreck CE, James J. 1968. Broth cultures of bacteria that attract female mosquitoes. Mosq News 28:33-38.

Schreck CE, Kline DL, Carlson DA. 1990. Mosquito attraction to substances from the skin of different humans. J Am Mosq Control Assoc 6:406-410.

Schreck CE, Smith N, Carlson DA, Price GD, Haile D, Godwin DR. 1981. A material isolated from human hands that attracts female mosquitoes. $J$ Chem Ecol 8:429-438.

Smallengange RC, Qiu YT, van Loon JJA, Takken W. 2005. Synergism between ammonia, lactic acid and carboxylic acids as Kaitomones in the host-seeking behavior of the malaria mosquito, Anopheles gambiae sensu stricta (Diptera: Culicidae). Chem Senses 30:145-152.

Smith CN, Smith N, Gouck HK, Weidhaas DE, Gilbert IH, Mayer MS, Smittle BJ, Hofbauer A. 1970. Llactic acid as a factor in the attraction of Aedes aegypti (Diptera: Culicidae) to human hosts. Ann Entomol Soc Am 63:760-770.

Takken W. 1991. The role of olfaction in host seeking of mosquitoes: a review. Insect Sci Appl 12:287-295.

Takken W, Kline DL. 1989. Carbon dioxide and 1octen-3-ol as mosquito attractants. $J$ Am Mosq Control Assoc 5:311-316. 